\title{
Remission makes its way to rheumatology
}

\author{
Tuulikki Sokka*1 and Heidi Mäkinen² \\ See related research by Saber et al., http://arthritis-research.com/content/12/3/R94
}

\begin{abstract}
Remission was a rare event, even in the most advanced rheumatology clinics, until recent times. However, in the early 1990s, it was chosen as the treatment goal and the primary outcome measure for the Finnish Rheumatoid Arthritis Combination Therapy (FIN-RACo) trial, which can be considered the beginning of remission's way to rheumatology. In addition to remission in patients with rheumatoid arthritis, remission in patients with psoriatic arthritis is now being studied, although remission criteria for psoriatic arthritis have yet to be defined. Better treatment results with more active treatment strategies and availability of biologic agents motivate rheumatologists to monitor their patients as part of usual rheumatology care.
\end{abstract}

Remission was once an unusual phenomenon in rheumatology, despite references to disease-modifying antirheumatic drugs (DMARDs) as 'remission-inducing'. In the previous issue of Arthritis Research \& Therapy, the study by Saber and colleagues [1] provides further evidence of remission as a reachable goal in a usual rheumatology clinic. The authors report a DAS28 (disease activity score using 28 joint counts) remission rate of $58 \%$ in psoriatic arthritis patients who were treated with anti-tumor necrosis factor therapy for 12 months.

Remission started its eventful and ambitious journey in the 1990s in patients with rheumatoid arthritis (RA). It was defined as the treatment goal and the primary outcome measure in the Finnish Rheumatoid Arthritis Combination Therapy (FIN-RACo) trial [2] in 1993, 6 years before the first biologic agent became available. Nonetheless, the results of the FIN-RACo trial were amazing: $42 \%$ of those who received a combination of conventional DMARDs were in remission 2 years after baseline, entirely without signs and symptoms of RA, and

*Correspondence: Tuulikki Sokka, tuulikki.sokka@ksshp.fi

'Jyväskylä Central Hospital, Keskussairaalantie 19, 40620 Jyväskylä, Finland Full list of author information is available at the end of the article
$68 \%$ met the DAS28 remission criteria [3]. The findings indicated that a strategy of 'tight control' appeared to be more important than a specific agent in the control of RA.

Subsequent studies confirmed the importance of a 'tight control' strategy directed to 'treat to target' according to a quantitative goal. The TICORA (Tight Control of Rheumatoid Arthritis) trial reported a remission rate of 65\% using conventional DMARDs. In the CIMESTRA (Cyclosporine, Methotrexate, Steroid in Rheumatoid Arthritis) trial, remission rates were 59\% and 54\% for DAS28 remission and $41 \%$ and $35 \%$ for American College of Rheumatology (ACR) remission at 2 years in the combination and monotherapy arms, respectively [4]. In the BeSt (Behandelstrategieën voor Reumatoide Artritis) study of treatment strategies for RA, $38 \%$ to $46 \%$ of patients in the four arms were in remission at the end of intervention [5].

At this time, remission rates for RA in usual clinical care are higher than in the past [6], though primarily in North America and Western Europe [7]. Similarly, the clinical status of RA patients who are treated actively in rheumatology clinics has improved substantially compared with previous decades $[8,9]$.

A single 'gold standard' measure is not available for disease activity in RA or other inflammatory joint diseases, and simple criteria for defining remission must include multiple measures. Preliminary remission criteria for RA were proposed by a committee of the American Rheumatism Association (now the ACR) in 1981 [10]. According to these criteria, remission is present if five of the following conditions are met: absence of morning stiffness, fatigue, joint pain, tenderness, and swelling and presence of normal erythrocyte sedimentation rate. However, these criteria are too stringent and are not based on real-world data; for example, mild pain is common in the population over age 50 , and $85 \%$ would not meet ACR remission criteria [11]. The use of less stringent definitions of remission such as remission according to DAS28 has opened rheumatology for the concept of remission in a large number of patients [12], as shown by Saber and colleagues [1] in patients with psoriatic arthritis.

Psoriatic arthritis is a multifaceted disease. Global remission should involve the absence of peripheral 
arthritis, spondylitis, enthesitis, dactylitis, and skin disease. Fifty-eight percent, a high percentage for DAS28 remission [1], may be an overestimate compared with a real remission rate. However, no consensus about remission in psoriatic arthritis exists, and various criteria have been used to define remission [13], just as various criteria were used to define remission in RA [7]. In both diseases, remission has been defined as the treatment target $[13,14]$.

Routine quantitative monitoring of rheumatology patients has been advocated for almost 3 decades. However, it appears that only the availability of biologic agents can direct rheumatologists' interest into routine monitoring of patients' pain, functional status, and disease activity. The patients of Saber and colleagues [1] were assessed every 3 months for disease activity and patient-reported outcomes. Remission is an achievable goal in rheumatology at this time, and routine monitoring of patients may make its way to rheumatology after a three-decade-long journey.

Finally, there is nothing new under the sun: The Health Assessment Questionnaire (HAQ) is the best predictor of the future [15] (in this case, remission). This observation by Saber and colleagues [1] confirms what many reports have been showing for the past 20 years: HAQ is the best predictor of mortality, work disability, functional status, and even joint replacements and health care costs.

\section{Abbreviations}

ACR, American College of Rheumatology; DAS28, disease activity score using 28 joint counts; DMARD, disease-modifying antirheumatic drug; FIN-RACo,

Finnish Rheumatoid Arthritis Combination Therapy; HAQ, Health Assessment Questionnaire; RA, rheumatoid arthritis.

\section{Competing interests}

The authors declare that they have no competing interests.

\section{Author details}

'Jyväskylä Central Hospital, Keskussairaalantie 19, 40620 Jyväskylä, Finland. 2Tampere University Hospital, Teiskontie 35, 33500 Tampere, Finland.

Published: 14 July 2010

\section{References}

1. Saber TP, Ng CT, Renard G, Lynch BM, Pontifex E, Walsh CAE, Grier A, Molloy M, Bresnihan B, FitzGerald O, Fearon U, Veale DJ: Remission in psoriatic arthritis: is it possible and how can it be predicted? Arthritis Res Ther 2010, 12:R94.

2. Möttönen T, Hannonen P, Leirisalo-Repo M, Nissilä M, Kautiainen H, Korpela M, Laasonen L, Julkunen $H$, Luukkainen R, Vuori K, Paimela L, Blåfield H, Hakala M, Ilva K, Yli-Kerttula U, Puolakka K, Järvinen P, Hakola M, Piirainen H, Ahonen J, Pälvimäki I, Forsberg S, Koota K, Friman C: Comparison of combination therapy with single-drug therapy in early rheumatoid arthritis: a randomised trial. FIN-RACo trial group. Lancet 1999, 353:1568-1573.

3. Mäkinen $\mathrm{H}$, Kautiainen $\mathrm{H}$, Hannonen $\mathrm{P}, \mathrm{Möttönen} \mathrm{T,} \mathrm{Leirisalo-Repo} \mathrm{M,}$
Laasonen L, Korpela M, Blåfield H, Hakola M, Sokka T: Sustained remission and reduced radiographic progression with combination disease modifying antirheumatic drugs in early rheumatoid arthritis. J Rheumatol 2007, 34:316-321.

4. Hetland ML, Stengaard-Pedersen $\mathrm{K}$, Junker P, Lottenburger T, Hansen I, Andersen LS, Tarp U, Svendsen A, Pedersen JK, Skjødt H, Lauridsen UB, Ellingsen T, Hansen GV, Lindegaard H, Vestergaard A, Jurik AG, Østergaard M, Hørslev-Petersen K; CIMESTRA study group: Aggressive combination therapy with intra-articular glucocorticoid injections and conventional disease-modifying anti-rheumatic drugs in early rheumatoid arthritis: second-year clinical and radiographic results from the CIMESTRA study. Ann Rheum Dis 2008, 67:815-822.

5. Goekoop-Ruiterman YP, de Vries-Bouwstra JK, Allaart CF, van Zeben D, Kerstens PJ, Hazes JM, Zwinderman AH, Ronday HK, Han KH, Westedt ML, Gerards AH, van Groenendael JH, Lems WF, van Krugten MV, Breedveld FC, Dijkmans BA: Clinical and radiographic outcomes of four different treatment strategies in patients with early rheumatoid arthritis (the BeSt study): a randomized, controlled trial. Arthritis Rheum 2005, 52:3381-3390.

6. Makinen $\mathrm{H}$, Kautiainen $\mathrm{H}$, Hannonen P, Sokka T: Frequency of remissions in early rheumatoid arthritis defined by 3 sets of criteria. A 5-year followup study. J Rheumatol 2005, 32:796-800.

7. Sokka T, Hetland ML, Mäkinen H, Kautiainen H, Hørslev-Petersen K, Luukkainen RK, Combe B, Badsha H, Drosos AA, Devlin J, Ferraccioli G, Morelli A, Hoekstra M, Majdan M, Sadkiewicz S, Belmonte M, Holmqvist AC, Choy E, Burmester GR, Tunc R, Dimić A, Nedović J, Stanković A, Bergman M, Toloza S, Pincus T; Questionnaires in Standard Monitoring of Patients With Rheumatoid Arthritis Group: Remission and rheumatoid arthritis: data on patients receiving usual care in twenty-four countries. Arthritis Rheum 2008, 58:2642-2651.

8. Pincus T, Sokka T, Kautiainen $\mathrm{H}$ : Patients seen for standard rheumatoid arthritis care have significantly better articular, radiographic, laboratory, and functional status in 2000 than in 1985. Arthritis Rheum 2005, 52:1009-1019.

9. Uhlig T, Heiberg T, Mowinckel P, Kvien TK: Rheumatoid arthritis is milder in the new millennium: health status in patients with rheumatoid arthritis 1994-2004. Ann Rheum Dis 2008, 67:1710-1715.

10. Pinals RS, Masi AT, Larsen RA: Preliminary criteria for clinical remission in rheumatoid arthritis. Arthritis Rheum 1981, 24:1308-1315.

11. Sokka T, Makinen H, Hannonen P, Pincus T: Most people over age 50 in the general population do not meet ACR remission criteria or OMERACT minimal disease activity criteria for rheumatoid arthritis. Rheumatology (Oxford) 2007, 46:1020-1023.

12. Makinen H, Hannonen P, Sokka T: Definitions of remission for rheumatoid arthritis and review of selected clinical cohorts and randomized clinical trials for the rate of remission. Clin Exp Rheumatol 2006, 24:S22-S28.

13. de Vlam K, Lories RJ: Remission in psoriatic arthritis. Curr Rheumatol Rep 2008, 10:297-302.

14. Smolen JS, Aletaha D, Bijlsma JW, Breedveld FC, Boumpas D, Burmester G, Combe B, Cutolo M, de Wit M, Dougados M, Emery P, Gibofsky A, GomezReino JJ, Haraoui B, Kalden J, Keystone EC, Kvien TK, McInnes I, Martin-Mola E, Montecucco C, Schoels M, van der Heijde D; T2T Expert Committee: Treating rheumatoid arthritis to target: recommendations of an international task force. Ann Rheum Dis 2010, 69:631-637.

15. Pincus T, Callahan LF, Sale WG, Brooks AL, Payne LE, Vaughn WK: Severe functional declines, work disability, and increased mortality in seventyfive rheumatoid arthritis patients studied over nine years. Arthritis Rheum $1984,27: 864-872$.

doi:10.1186/ar3059

Cite this article as: Sokka T, Mäkinen H: Remission makes its way to

rheumatology. Arthritis Research \& Therapy 2010, 12:129. 